This is the version of the article accepted for publication in Multilingua published by De Gruyter: https://doi.org/10.1515/multi-2018-0002

Accepted version downloaded from SOAS Research Online: http://eprints.soas.ac.uk/26349

JULIA SALLABANK

SOAS UNIVERSITY OF LONDON

Thornhaugh Street

London WC1H OXG

UK

email: js72@soas.ac.uk

Submission Title:

Language planning and language ideologies in Guernsey

Submission for Special Issue:

Re-imagining Language Revitalization in Contemporary Europe

Guest Editors:

Sabina Perrino (Binghamton University, SUNY)

Andrea Leone-Pizzighella (University of Pennsylvania) 


\title{
Language planning and language ideologies in Guernsey
}

Julia Sallabank

\begin{abstract}
The Bailiwick of Guernsey is a small, semi-autonomous archipelago in the English Channel. Although it is a British Crown dependency and part of the British Isles, it has its own parliament and does not belong to the United Kingdom or the European Union. This unusual geopolitical situation means that the nation-state has little relevance. It is only recently that the indigenous former vernacular has been accorded any worth, at either grass-roots or government level: as its vitality declines (increasingly rapidly), its perceived value for individual and collective identification has grown. Although public opinion overtly supports indigenous language maintenance, and increasing its vitality is a stated aim (e.g., a government Language Commission was announced in 2012), effective top-down measures to increase the number and fluency of speakers appear to be low on the agenda. This article explores the implications of this socio-political background for language policy. It discusses language-related activities which reveal a lack of ideological clarification and strategic direction at all levels, compounded by issues of control, epistemic stance and language ownership.
\end{abstract}

Keywords: Guernsey, endangered languages, ideologies, language policy, language revitalization 


\section{Introduction}

\subsection{Socio-political background}

The small island of Guernsey in the English Channel is considerably better known than its size might indicate, thanks principally to its breed of cattle and dairy products, which have been exported worldwide. At various times products such as granite, woollen sweaters, grapes, tomatoes, and flowers have been important for the island's economy; currently the chief industries are tourism and finance (a by-product of the Channel Islands' fiscal independence from Great Britain). The Channel Islands are also known as the only part of the British Isles to be occupied by the Germans in the Second World War. ${ }^{1}$

The term 'Channel Islands' refers to a geographical rather than a political entity. They are divided into the Bailiwick of Guernsey and its neighbour Jersey, which are British Crown Dependencies: they each have their own parliaments, and autonomy with regard to domestic and financial policies. They are not part of the United Kingdom or the European Union, although they are in the British Isles. The Bailiwick of Guernsey comprises the islands of Guernsey (approximate population 63,000), Alderney (2400), Sark (c.600) and several smaller islands. This article deals primarily with Guernesiais, the indigenous language of the main island of Guernsey, which has a land area of about 24 square miles $\left(62 \mathrm{~km}^{2}\right)$.

\subsection{Sociolinguistic background}

All Channel Islands language varieties are severely endangered in the wake of substantial Anglicization during the $20^{\text {th }}$ century. Through our research, the author and local collaborators estimate that there are only 100-200 fluent speakers of Guernesiais, the majority

\footnotetext{
${ }^{1}$ This has featured in numerous books, e.g. Barrows and Shaffer (2008), which at the time of writing this article is being filmedhas been made into a film.
} 
being native speakers aged 80 or over (Sallabank 2013; Sallabank \& Marquis 2013). $\stackrel{2}{ }$

Political autonomy is often thought to support the status of local languages, but although the islands have had a large degree of autonomy since 1204, their indigenous languages now have very few speakers. Reports in local news media in late 2016 (Guernsey Press 2016; Scott 2015) suggested that there may be only ten proficient speakers aged under 65 , of whom perhaps only two are under 50 at the time of writing. ${ }^{3}$

Historically attitudes towards the indigenous language varieties have been quite negative; it is only since the late $20^{\text {th }}$ century that views have started to change (Sallabank 2013). As the vitality of the indigenous languages declines, the perceived value of "having" a language for individual and collective identification has grown. In recent years, Guernesiais (or the idea of Guernesiais) has been promoted by some politicians as valuable for identity, "island branding" and distinctiveness, and public opinion is perceived as broadly in favour of language maintenance/revitalization (Sallabank 2013), which means that politicians cannot now afford to be seen as anti-Guernesiais. However, as this article explores, this has not yet led to the government taking a lead on language revitalization.

Since 2007 there have been two main government-supported approaches towards language policy: firstly, the appointment of a Language Support Officer from 2008 to 2011, and secondly, the announcement of a Guernsey Language Commission (GLC) in 2012. However, these initiatives were not accompanied by substantial funding, nor by coordinated strategic planning. By the time of writing the GLC had not yet been formally established as a legal entity, and activities organised in its name are administered one day a week by an Access and Learning Manager at Guernsey Museum. By contrast, the Sports and Arts Commissions, on which the Language Commission was modelled, have formal constitutions,

\footnotetext{
${ }^{2}$ When discussing language vitality with the author in April 2018, language activists expressed the view that most truly fluent speakers of Guernesiais are now aged $90+$; anyone younger should be considered a semispeaker.

${ }^{3}$ One of these is bringing up a child bilingually, who however cannot yet be considered a fluent speaker.
} 
strategies, a budget for grants, and raise significant funding from non-governmental sources. In the field of biodiversity, with which parallels with language endangerment have frequently been drawn (e.g. Skutnabb-Kangas et al. 2003; Sutherland 2003), the island parliament agreed on a Biodiversity Strategy in 2015, including a Partnership Group to advise on effective delivery, followed by recruitment of a Biodiversity Education Officer in 2017. An editorial dated November $10^{\text {th }}, 2016$ in the Guernsey Press daily newspaper (Guernsey Press 2016), which has wide circulation in the island, commented that language "is something easy to offer broad support to, but if Guernesiais is to be saved as a live language and its use grow, efforts will need to go beyond phrases in a plan or translating States job titles on business cards."

The editorial claims that there is a "whiff of tokenism" in the level and nature of involvement of the States [of Deliberation, the Guernsey parliament] in language planning, i.e. that it remains at a minimal, symbolic level. Confirming that the Language Commission "has never had the formal recognition afforded to its cousins in sport and arts," it notes that "it is difficult to judge its value or success as any business plan or accounts are absent from its webpage. Any targets have remained vague since its inception" (Guernsey Press 2016). In the absence of official policy, it is necessary to examine policy-making at other levels. Despite the lack of coordinated planning for language revitalization, and public discussion which might lead to agreed strategies and ideological clarification, underlying ideologies and trends can be identified which influence the character, direction and outcomes of languagerelated activities, which together arguably constitute "unplanned language planning" (Baldauf 1994) and de facto policy.

\subsection{Methodology}


This article is based on research conducted in Guernsey since 2000. It draws on the author's $\mathrm{PhD}$ and continuing research into language attitudes and identities, policies and ideologies, and language revitalization, as well as insights gained through language documentation. The research instruments include ethnographic interviews; and-participant observation of

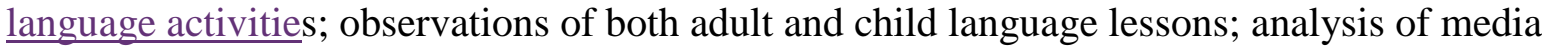
and social media treatment of language themes; questionnaires and semi-structured interviews. The author has also been invited to advise Guernsey government officials on language policy.

\section{Language revitalization: policies and ideologies}

\subsection{Language policy: levels and domains}

The term language policy is often assumed to refer to decisions made at governmental or institutional level; however, as noted by Spolsky (2004: 43) and McCarty (2011), language policies are formulated and implemented at all levels of society and in all domains of use, from intergovernmental bodies to families and individuals. Spolsky's model of language policy $(2004 ; 2009)$ has three components:

- language practices - the habitual pattern of selecting among the varieties that make up [a community's] linguistic repertoire;

- language beliefs or ideology _-beliefs about language and language use;

- any specific efforts to modify or influence that practice by any kind of language intervention, planning or management (Spolsky 2004: 5).

Focusing on the last of these, Nekvapil and Nekula (2006: 311) emphasize that:

Language management takes place within social networks of various scopes. It does not occur only in various state organizations ... but also in individual companies, schools, media, associations, families as well as individual speakers in particular 
interactions. The theory of language management therefore deals not only with the macro-social dimension, but also with the micro-social one.

According to Joshua Fishman, one of the founders of the field of study of endangered languages, the most important locus in reversing language shift is intergenerational mother tongue transmission in the family (1991: 113). However, as pointed out by Romaine (2006), the majority of language campaigners and planners around the world seem to ignore Fishman's advice, focusing instead on "high stakes" spheres such as formal education and language legislation. For a critically endangered language such as Guernesiais, which to date has attained none of these, it is arguable that intergenerational transmission needs to take a back seat to adult language acquisition: without proficient adult speakers there can be no intergenerational transmission. Moreover, the demographics of heritage language learning in Guernsey - the fact that most learners are aged 40 and above (Sallabank \& Marquis 2017b) provide an opportunity to rethink the target audience for revitalization efforts. Peer to peer adult transmission and new speaker development may well be a more realistic strategy, at least for highly endangered languages, than the traditional view of family transmission as essential for language vitality.

It has been suggested that the majority of language revitalization programmes worldwide have been unsuccessful (Grenoble \& Whaley 2006: ix). Grenoble \& Whaley note that a "longer-term, multifaceted program, one which requires a range of resources and much personal dedication, is needed," adding that where successes do occur in language revitalization, they result, perhaps without exception, from the efforts of people who want to speak a local language, and want their friends and neighbors to as well. (Grenoble \& Whaley 2006: ix) However, small-scale, grass-roots efforts are often undocumented, unevaluated, and unreported in the academic literature. Macro-social language policy often ignores community 
use and attitudes at the local level, focusing instead on schools and compulsion, which can impact uptake and effectiveness. Dorian (1987: 66) notes that in Ireland "compulsory Irish" created aversion towards the language, while Fennell (1981) describes how after Irish independence in the 1920s it was assumed that state bureaucracy could save the Gaeltacht (the areas where Irish is spoken), with little consultation of local people or representation of their views in decision-making. Grenoble and Whaley (2006) argue that Soviet language policy, while ostensibly supporting minority languages, led to Siberian peoples becoming passive recipients of language planning rather than active participants, and thus to a lack of enthusiasm for revitalization projects. It is thus clear that an examination of language revitalization policy at the local level should include the micro-social dimension. However, in Guernsey there is no simple macro-micro dichotomy: both GLC-run and "grass-roots" initiatives tend to be symbolic, if not in intention then in effect. In the absence of informed public discussion of priorities and effectiveness, or what Fishman (1991: 397) calls ideological clarification, both bottom-up and top-down language policies, practices and management are highly likely to be affected by "folk linguistic" societal language ideologies (Nieldzielski \& Preston 2003): common or received beliefs and assumptions about language. Language policies may thus be implicit rather than overt.

\subsection{Epistemic stance and native-speakerism}

Language policy-making in Guernsey is complicated by a legacy of ideological rifts and interpersonal differences, particularly concerning authenticity, legitimacy, and what Sallabank \& Marquis (2017b2017) have called language ownership. This, which-is related to epistemic stance or who owns the knowledge: who has the right to evaluate language and to define what counts as right or wrong (Sharrock 1974; Avineri 2014). Jaffe (2012: 7) notes that 'speakers may use epistemic stance in pursuit of the social capital that accrues to being 
recognized as having authentic or authoritative knowledge'. This hasThese issues have understandably led to some reluctance to tackle the potential "can of worms" that might be opened by attempts at pronouncements on language matters.

Epistemic stance in this context is related to native-speakerism, a pervasive ideology within both language teaching and endangered language revitalization, which is characterized by the belief that the native_-speaker is the repository and guardian of the true language (Davies 1991; Holliday 2005). The notion that native speakers hold superior linguistic expertise mitigates forsupports the preservation of a privileged in-group and their epistemic positioning (Sallabank \& Marquis 2017b2017). Native-speakerism entails low expectations of the ability of non-native speakers to become fluent and to teach the language. It exemplifies a static language ideology (Marquis \& Sallabank 2014) which finds it difficult to conceive of an endangered language being used for modern purposes or by younger generations, and thus rejects neologisms and language change. In Guernsey, this stance is commonly referred to as traditionalist.

However, in an endangered language context, people considered to be native speakers are not always fluent (Sallabank \& Marquis 2013). Most are aged 80+- and ifn many cases former interlocutors are no longer alive: one recounted how he had had nobody to speak Guernesiais to since his mother died in 1995. Attrition is therefore commonplace, and epistemic positioning becomes more complicated.

\subsection{Language or personal revitalization?}

In many activities generally included under the umbrella of "language revitalization", outcomes are less salient for participants than the enactment of the activity. Indeed, at smallscale, grass-roots level, there may be no planned outcomes or deliverables. Such activities 
arguably perform a similar function to emblematic language (Benor 2010) or the emotive mode (Matras et al. 2007:149):

The principal feature of the emotive mode is its explicit appeal to a very particular domain of values, attitudes and cultural knowledge that is shared between speaker and hearer. Use of the emotive mode triggers the activation of special, intimate knowledge and its integration into the utterance, creating a special bond between the speaker and hearer.

Avineri (2012) proposes the term metalinguistic community for use of a language to create social bonds, without necessarily involving communication in that language. It is similar to what Shandler (2006) has termed post-vernacular language use: where a former vernacular is no longer widely used in a community, formulaic phrases or sayings, especially in performance arts, can become a vehicle for symbolic identification with perceived ethnic roots and other like-minded community members.

The use of symbolic Guernesiais in what might be termed the personal linguistic landscape (see Section 3.5) extends the notion of emblematic language or emotive mode from oral insertions to the use of activities and objects to create a "special bond" via language; another aspect of the creation of a metalinguistic community, which has the idea of language as one of its features. This can be seen in activities described in Section 3. Use of an endangered language for identity-reinforcement and personal growth is increasingly recognised as a motivator in participation in language revitalization-related activity (King 2014).

Although an a priori link between language and identity has been criticized by postmodern-influenced commentators such as Duchêne \& Heller (2007) and Costa (2017), its strategic value in language revitalization has been recognized (e.g. Kroskrity \& Field 2009; 
Meek 2011). For many members of endangered language communities, as suggested by Moya (2000: 8), “cultural identities can be enabling, enlightening, and enriching structures of attachment and feeling ... significant modes by which people experience, understand, and know the world"; what is more, they can be experienced as emancipating after centuries of denigration. All three dimensions of discursive construction of identity distinguished by Bamberg et al. (2011) can be observed:

(a) the navigation of agency in terms of a person-to-world versus a world-to-person directionality (active attempts to reverse language shift at a personal level); (b) the differentiation between self and other as a way to navigate between uniqueness and a communal sense of belonging and being the same as others (Guernesiais proficiency is a personal achievement, but requires interlocutors; a "secret language" was also mentioned as motivating by some interviewees);

(c) the navigation of sameness and change across one's biography or parts thereof (agency in reversing personal language loss).

Language revitalization in Guernsey is thus linked to personal valorization, but in different ways for different stakeholders and participants. For "traditionalists", notions of legitimacy relate to who has the authority to decide how language should be used, and what form(s) it should take. The recognition of elders' expertise is an important issue, although this may be expressed in other ways, such as concern that traditional ways of speaking should not be diluted by what they see as imperfect acquisition by younger adult learners, or contact with English. "Rememberers", or what linguists term semi-, passive or latent speakers (Dorian 1980; Grinevald \& Bert 2011; Basham \& Fathman 2008), value the sense of empowerment and emancipation that is experienced through regaining active mastery of a language that they are reconstructing as a key part of their sense of identity, as well as the social interaction which is a key element of the group's activities (see Section 3.3). For adult second language 
(L2) learners of Guernesiais ${ }^{4}$, key motivators include reconnection with identity and roots, as well as empowerment. A minority mentioned intellectual interest, as did some Rememberers.

\section{Guernesiais language activities}

In this Section I examine examples of activities in relation to the theoretical framework presented in Section 2, and try to discern their ostensible aims and apparent outcomes, as well as the discourses or ideologies of language that they appear to exemplify or reveal.

An array of language-related activities is organised by various groups and individuals, as well as in the name of the Language Commission. The lack of an overall language strategy and of an effective funding stream has meant that activities tend to be "scattergun": there appears to be little prioritization or coordination, despite overlap in participation.

\subsection{Festivals, concerts and language competitions}

These are the most visible language-related activities, and are therefore important for the image of Guernesiais culture conveyed to the general public. They are dominated by traditionalist interpretations of language and culture, with songs and plays typically performed by older people wearing old-fashioned clothes. The genres of performances tend to cater for the age range of the performers, and the tone is nostalgic, harking back to the "language of our forefathers", in the words of an adjudicator; as noted in Section 2.2, in this eontext the language is presented as associated with the past. This image of Guernsey culture is not necessarily attractive to younger generations:

Learning Guernsey French is not cool, there is nothing to encourage the younger generation - the Eisteddfod ${ }^{5}$ is mostly for older people. (teenage female informant)

\footnotetext{
${ }^{4}$ Surveyed and interviewed in British Academy-funded research, 2012-14; see Sallabank \& Marquis (z017b2017).
} 
Awareness-raising via media coverage for such activities is therefore double-edged, if they promote a "language of the past" which is seen by younger people as irrelevant to their lives. For the participants, festivals and performances play an important role in promoting pride in their authentic, traditional identity and in validating their expertise. As well as reinforcing epistemic positioning, for speakers of a language long denigrated as a Low diglossic partner to French, this valorization is important. The formation of a metalinguistic community thus has events also have an important social function in bringing speakers together, since participants are increasingly "vestigial users ... socially isolated old folks" (Fishman 1991: 88, describing the least vital stage of his Graded Intergenerational Disruption Scale).

\subsection{Activities for children}

It is common for language revitalization movements to focus their attention on child language learning, most often through schools (Romaine 2006). However, Guernesiais is not officially recognised, and is not included in the school curriculum. The Guernsey Language

Commission (GLC) website states:

Guernésiais ${ }^{6}$ is not currently taught in Guernsey schools. Some teachers choose to feature some language in their classroom and lessons but the language does not have a designated slot in the timetable. At some schools, it is offered as an option afterschool or during lunchtimes and these sessions are taught by an independent team of volunteers (GLC, no date a).

These extra-curricular sessions generally run for 30 minutes a week during the school year, equivalent to 20 hours of tuition per year. They are popularAt their height they were running

\footnotetext{
${ }^{5}$ One of the festivals referred to: an annual competitive cultural festival which showcases island talent in a wide range of artistic genres. As well as languages including 'Guernsey French' (Guernesiais), French, and Portuguese, it includes music, cake-making, and artistic roller-skating.

${ }^{6}$ Spelling is a vexed topic and a litmus of ideological debates (see Author-Sallabank and Marquis 2017).

"Traditionalists" prefer to use French conventions, but this leads to frequent mispronunciation. For example, the acute accent in Guernésiais is often interpreted as a stress marker (which is why I omit it), whereas the correct pronunciation is /'-d dzernezjer/, with the stress on the first syllable.
} 
in 8 of the 14 primary schools, with between 5 and 15 pupils attending each class observed; although teachers report a drop-out rate of around half the pupils over a school year. There are no data on reasons, but as an extra-curricular activity the sessions have to compete with other clubs such as sports and crafts. Another factor may be that there is no syllabus or progression, and very few of the volunteer teachers have any teacher training. It is therefore not surprising that the author is not aware of any student who has achieved higher than beginner level in these lessons - indeed, in one lesson observed, a child who had been attending for five years was unable to formulate an utterance.

The lessons are mainly taught by retired people who consider themselves to be native speakers of Guernesiais, and who tend to follow a traditionalist viewpoint as discussed above. A strong version of this ideological stance does not allow the development of strategies for filling lexical gaps. Thus, in one observed lesson, when teaching terms for items of clothing, a volunteer teacher was unable to find a word for a polo shirt, which several of the children were wearing. She refused to use cminse, the usual word for a shirt, saying "a sports shirt is not a cminse". This vignette illustrates a mismatch between the ostensible aim of teaching the language to children, and reluctance to countenance language change or adaptation to young people's needs. Thus, a strong interpretation of authenticity may inhibit development of language that is relevant to children's lives, and hence impede active use of Guernesiais by younger generations. ${ }^{7}$ As discussed in Section 2.3, the function of these lessons may not be effective language transmission so much as valorization of traditional speakers, which is a valid aim in its own right if acknowledged, but not necessarily the same as language revitalization or teaching.

Lessons and performances are relatively formal domains of language use, and in schools and language competitions especially, there is a focus on "correctness". However,

\footnotetext{
${ }^{7}$ For more on this topic, see Sallabank 2018.
} 
Guernesiais is not standardized or even fully described. Guernesiais was in a diglossic relationship with French for hundreds of years, so notions of "correctness" are influenced by an underlying linguistic inferiority complex (Sallabank 2013; Marquis \& Sallabank 2017a). This is compounded by pervasive language attrition, which means that performances and lessons frequently converge towards French. If this leads to convergence, it may counteract the desire for a unique linguistic identity which is a motivator for some politicians and activists.

Pre-school language exposure is another common activity of language revitalization movements worldwide. Immersion pre-schools such as Mudiad Meithrin in Wales (Cole \& Williams 2004) or language nests in New Zealand and Hawai'i (Grenoble \& Whaley 2006; Hinton \& Hale 2002) are seen as particularly effective. There are no similar kindergartens using Guernesiais, although some private pre-schools teach a few words. There is also Les Bibides, one of the range of activities run under the umbrella of the GLC:

A toddler group with a flavour of Guernésiais. Children up to the age of 7 are welcome. Tea, coffee or squash will be provided. ... Please do extend the invite to grandparents and great grandparents who might be interested or know a few words of the language (GLC 2017).

This announcement is careful not to claim that any intergenerational language transmission will result (especially as the sessions are 45 minutes long and take place approximately every six weeks), although some participants observed were under that impression: "they're so young, they're bound to pick it up", indicating both beliefs and misunderstandings regarding child language acquisition.

A positive impact of Les Bibides seems to have been awareness-raising among audiences that other efforts do not reach; some participants expressed a lack of awareness of other language activities, while others have gone on to attend adult lessons or to become 
more active in language campaigning. It is also noticeable that in some cases three generations of a family are attending Les Bibides, and that the grandparents are often "passive" or "latent" speakers of Guernesiais (Basham \& Fathman 2008; Grinevald \& Bert 2011); it is hoped that (great-) grandparents might be inspired to speak Guernesiais with children. Efforts to re-activate latent speakers' language knowledge will be discussed below.

\subsection{Social activities}

The use of an endangered language in communicative settings is a key element of language revitalization, so activities are organised to increase opportunities to hear and speak Guernesiais.

The second-oldest language-related association in Guernsey, L'Assembllaïe d'Guernésiais [The Assembly of Guernsey People] was founded in 1956. Although its original task was to instigate the Dictiounnaire Angllais-Guernésiais [English-Guernesiais Dictionary] (De Garis 1967), L'Assembllaïe became principally a forum for Guernesiais speakers to interact socially, focusing on the maintenance of the (then) speaker community rather than on attracting new speakers (which was unheard-of at the time). It has organises primarily sociald events such as eencerts, dinners, games evenings, etc. which, like the cultural activities-performances discussed above, cater for the tastes and age range of the membership (which overlaps to a large extent with the audiences at performances). However, as the age profile of speakers increases, an increasing proportion of people who attend these

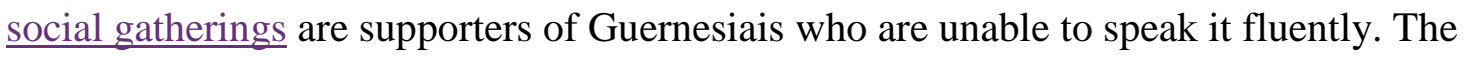

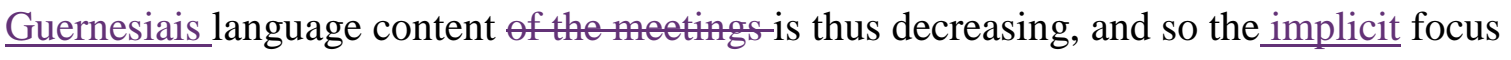
becomes moreshifts towards -a metalinguistic "nostalgic (cf. 'romantic') or aspirational" notion of community (Coupland 2010: 107), or the idea or nostalgia of languagea, rather thanand away from rebuilding an authentic language community through linguistic practice. 
Avineri's (2012) concept of metalinguistic community is also relevant here: the events

reinforce social bonds through the idea of language, without necessarily involving

communication in that language.

The GLC organises monthly sessions known as "Speed Patois", 8 usually in pubs but also at other locations (GLC 2016). These are based on a "speed dating" format of short conversations, and are attended by speakers and learners of all ages and abilities. The sessions have received highly positive responses and are perceived as a non-threatening forum for older yet socially integrated speakers (including traditionalists), latent speakers, and learners to interact.

The most recent informal group to emerge call themselves "The Rememberers" (in Guernesiais, Les Rallumeurs or "re-kindlers"). They are mainly aged 55-70 and in some cases have not used Guernesiais for 50 years. Informants have reported that parents used Guernesiais as a "secret language" to each other, or that they stopped speaking Guernesiais after discouragement at school. Often Rememberers do not have the confidence to speak spontaneously in their heritage language, even to their own families - this is a reason why many people prefer to use the language in the relatively predictable, rehearsable environment of a performance or classroom. People who have such implicit language knowledge can constitute an untapped reservoir of expertise for language documentation and revitalization. Although in Grinevald \& Bert's (2011) taxonomy, semi-speakers are more fluent than rememberers, non-disparaging terminology is important to community members and especially to language activists, for whom Rememberers or Rallumeurs sounds more positive and pro-active.

\footnotetext{
${ }^{8}$ The low status of Guernsey's language is reflected by the fact that it does not even have an official name. It is often known as Patois, which in French has- connotations of inferiority means "incorrect dialect" (see the Larousse dictionary definition at https://www.larousse.fr/dictionnaires/francais/patois/58677, accessed May 18th, 2018). Many Guernsey people do not necessarily see the term Patois as derogatory or know its connotations in French; language activists are more likely to know these connotations and to object to this name.
} 
The Rememberers meet approximately weekly to chat in Guernesiais, with the goal of making substantive efforts to re-activate receptive competence into active use, including both fluency and accuracy - topics often include obscure words or grammatical points. They describe their motivations as social purposes and "for enjoyment", as well as to increase their self-confidence and for personal empowerment (see Section 2.3). Although the overt focus on increasing fluency promotes (re)building an active linguistic community, not merely a metalinguistic community, the group caters specifically for heritage language learners who have-people with a memory of intergenerational transmission of Guernesiais, rather than for second language (L2) learners or new speakers, and thus may not contribute towards "new users or uses" (a definition of revitalization by Romaine 2006: 464) or expansion of the speaker base in the long term. Nevertheless, it is a relatively rare initiative in that it focuses on increasing active fluency rather than symbolic use-or a metalinguistic community, to which many language activities are arguably limited.

One impetus for the creation of the Rememberers as a distinct grouping was that some had been attending adult language classes, but like heritage language learners (Valdés 2005, among others), the teacher found that they had distinct and quite different characteristics and needs compared to ab initio second language learners. As described by Basham \& Fathman (2008), latent speakers such as the Rememberers have good pronunciation and intonation, strong listening comprehension, and substantial implicit awareness, yet little overt knowledge of language structures; they often have a low estimation of their own skills. Rememberers may consider themselves to be more authentic than new speakers, but not as having the same legitimacy as native speakers, who retain their ideological primacy as role-models. Rememberers may unexpectedly recollect structures and vocabulary, and be frustrated at the slow pace of lessons, yet make errors in their production and be unable to learn new language. These different foci and requirements led the teacher to organise separate sessions 
for L2 learners and Rememberers and L2 learners, which complement the Rememberers' own informal meetings. Rememberers also contribute to other initiatives such as Speed Patois, walks and visits to places of interest.

\subsection{Guernesiais in the linguistic landscape}

The term linguistic landscape is defined as the "visibility and salience of languages on public and commercial signs in a given territory or region" (Landry \& Bourhis 1997: 23). Guernsey does not have a policy like the Isle of Man, to replace official signage with bilingual versions as replacement becomes necessary, which is seen as a cost-neutral strategy to gradually increase the presence of Manx in the linguistic landscape or print environment. Indeed, there have been reports that some bilingual or Guernesiais signs (e.g. Bianv'ue dans not' paraisse, "welcome to our parish") were blocked by planning officials, indicating a lack of joined-up thinking consensus and very different ideological positions in governmental policy. Nevertheless, the amount of Guernesiais in the linguistic landscape has been growing steadily: in both public signage (e.g. La Piache d'la Libératiaon, 'Liberation Square'), and in private company branding, for example, La Coupaie: 'Cupful' coffee, beermats (some of which are not reprintable), or the latest addition, Poïn: 'Bread' bakery. One company whose translations were originally criticised now sponsors a free translation service (managed by the Language Commission), whose services are in increasing demand (GLC, no date c). Popular genres for which translations are requested include tattoos, house names, jewellery, mottoes or slogans (e.g. 'love hard'), and toasts for weddings. These extend the notion of linguistic landscape beyond its usual interpretation as public signage, into both broader and more intimate areas, as well as into new genres which can present challenges to translate (Yan Marquis, personal communication, October 2017). Jewellery inscribed with sayings in Guernesiais is very popular, as well as clothing: one website which sells T-shirts with the 
words collymochon 'snail' and bourdain 'bee' claims "this t-shirt is helping to keep our local language alive" (Iris \& Dora, no date). Such instances promote an overt link between language and identity, as well as place branding and marketization of language, and discourses about what language revitalization means. However, as noted in the Introduction, for such purposes fluency in Guernesiais is not necessary - except on the part of the translator - indicating post-vernacular, symbolic beliefs about what language revitalization means.

Endangered language supporters are under pressure to extend their presence into the digital linguistic landscape, which is perceived as a necessary part of revitalization. Guernesiais is increasingly visible online through numerous YouTube videos made and uploaded by the Guernsey Language Commission (GLC, no date b). These include lessons, songs, interviews, and conversations, and often relate to non-virtual language activities. As discussed above, the selection and rationale can seem somewhat eclectic.

As social media assumes a major role in the lives and identities of many people, a language app is seen as a "must-have" for language revitalization movements. In summer 2017 a pilot app was produced by the Digital Greenhouse, an initiative established by the States of Guernsey "to act as a focal point for the growth of the digital and creative sector" (Digital Greenhouse 2017a), in collaboration with Guernsey researcher and language teacher Yan Marquis, with sponsorship from a local finance company. Although the Digital Greenhouse is a government scheme, the app initiative was independent of centralized language policy-:

The app contains audio files of useful phrases such as "Would you like a drink?", and was intended as an introductory trial. As stated on the project website,

Our short-term aim is to use this small, taster content as a 'proof of concept,' gaining interest and momentum and hopefully providing data to gauge people's interest. Our longer term goal would then be to use the data and experiences of users over the 
summer period to then look at developing a purpose build language app with greater functionality. (Digital Greenhouse 2017b)

The target audience is obviously younger than the majority of speakers and current learners of Guernesiais, most of whom are over 40 . Versions of the app were distributed for summer events such as the Sark Folk Festival and agricultural shows, which are major social events in Guernsey. By the time of writingthe end of 2017 it had had over 700 downloads, with an average "time of engagement" of 20 minutes, which is longer than is usual for apps: users are not only looking briefly at the app, but are engaging with it for a considerable length of time. It has also been the focus of more traditional media attention, with a radio presenter commenting that it had "done more to save the language than anyone before" (interview with app developers, BBC 2017). Buoyed by its success, the developers are now looking inte the pessibility offor funding to produceing a more substantive app which would include progression in language learning. Multimedia materials including pronunciation guidance were identified as a key need in the study of adult learners of Guernesiais reported in Sallabank \& Marquis (2017b2017), so as well as its symbolic awareness-raising role, this app may indeed contribute to developing "new users or uses" for Guernesiais.

\section{Conclusions}

This article has looked at small-scale language support activities in an attempt to discern underlying beliefs and ideologies in bottom-up or unplanned language management in Guernsey. As can be seen from the examples above, language revitalization in the Guernsey context is constantly being negotiated at the interpersonal level in very specific ways, although without overt ideological clarification. The activities described in Section 3 are imaginative and enjoyable, and can raise language awareness and valorize speakers. They are however discrete, rather than linked elements in a coordinated language plan. As noted 
earlier, language policies may be implicit rather than overt, so need to be grasped through examination of unstated ideologies. As noted, in such a small community, with an even smaller core of language enthusiasts, the distinction between macro- and micro-level policies dwindles, so that officials responsible for language policy continue the long-standing practice of discrete, uncoordinated, small-scale activities without fully articulated planned outcomes. Thus it appears that the building blocks of language policy are present, without the structure. The Guernsey Press editorial cited in Section 1.2 goes to the core of the problem by asking what the aim of language policy should be:

The island needs to decide whether it is happy for Guernesiais to be consigned to history, perhaps remaining as a quirky relic spoken among the interested few and held in ghostly recordings, or whether a concerted effort, backed by more than just words, is needed. (Guernsey Press 2016)

It also reflects the changing view of Guernesiais from being seen as a "language of the past", stressing that

The commission [GLC] was seen as a way to guide and support existing groups and individuals who were already involved in the language. They are not the people that need to be won over.

Until recently, there has been a tendency to prioritize the maintenance of the existing өr-traditional speaker community and their epistemic status as knowledge holders, ignoring the voices and actual and potential contributions of new speakers (who are arguably vital to the future of any endangered language), or of non-speaker supporters. This comment, and the language app discussed above, indicate that this attitude may be changing.

What, then, does language revitalization mean in a small community such as Guernsey? In a BBC News report on January 20th, 2015, a representative from the Guernsey Language Commission stated that "Language is very emotive and part of your identity" 
(Scott 2015), adding that "In this vanilla-coloured world, it's important people appreciate what's on their doorstep and that includes the quirky nature of indigenous languages." Emblematic language use may be sufficient for identity-reinforcement and personal growth. Many participants in Guernsey language activities do so to connect or reconnect with heritage and culture, or for enjoyment. It may even be that enjoyment or personal empowerment are more sustainable motivations for involvement than an abstract, undefined notion of "saving the language", although both of these may reflect nostalgic, idealized views of both language and community-

In the absence of political strategy or ideological clarification, language policy at the local level seems to be more and more personalized. The emergence of The Rememberers is a rare example of effectiveness in micro-language planning, if this is measured in terms of the stated aim of increasing participants' frequency and fluency in using Guernesiais. If this $\underline{\text { the }}$ efforts of these heritage language learners could be combined with effective teaching and mentoring for new $\underline{\mathrm{L} 2}$ speakers, it could make a considerable contribution towards rebuilding a language community from the bottom up. It is thus possible that even in the absence of topdown leadership and overt ideological clarification, and in the face of pervasive static and symbolic language ideologies, language revitalization may be effected from the bottom up through the discursive practices of middle-aged people, albeit on a small scale, without recourse to official policy.

\section{References}

Avineri, Netta. 2012. Heritage language socialization practices in secular Yiddish educational contexts: The creation of a metalinguistic community. Los Angeles: University of California $\mathrm{PhD}$ dissertation. 
Avineri, Netta. 2014. Engaging the "Other" in Expanded Communities of Practice: Identity, Indexicality, and Epistemics in Academic-Public Interactions. Anthropology News Series "Future Publics, Current Engagements".

Baldauf, R. B., Jr. 1994. “Unplanned” Language Policy and Planning. Annual Review of Applied Linguistics 14. 82-89.

Bamberg, Michael, Anna De Fina \& Deborah Schiffrin. 2011. Discourse and Identity Construction. In Seth J. Schwartz, Koen Luyckx and Vivian L. Vignoles (eds.): The handbook of identity theory and research, 177-199. Berlin: Springer.

Barrows, Annie \& Mary Ann Shaffer. 2008. The Guernsey literary and potato peel pie society. Random House.

Basham, Charlotte \& Anne Fathman 2008. The latent speaker: attaining adult fluency in an endangered language. International Journal of Bilingual Education and Bilingualism 11. 577-597.

Scott, Jenny. 2015. Are lost languages coming back? BBC News. http://www.bbc.co.uk/news/uk-england-30280239, accessed November 20 ${ }^{\text {th }}, 2017$.

BBC, 2017. The Jenny Kendall-Tobias Show, interview with Lucy Witham and Yan Marquis, July $14^{\text {th }}, 2017,2$ hrs 23 mins into programme. http://www.bbc.co.uk/programmes/p0569zkb\#play (accessed July 16 ${ }^{\text {th }}, 2017$ ).

Benor, Sarah Bunin. 2010. Ethnolinguistic repertoire: Shifting the analytic focus in language and ethnicity. Journal of Sociolinguistics 14.159-183.

Cole, Alistair \& Colin Williams. 2004. Institutions, identities and lesser-used languages in Wales and Brittany. Regional \& Federal Studies 14 (4) 4. 554-579.Costa, James. 2017. Revitalising language in Provence: A critical approach. Oxford: Wiley, Backwell / the Philological Society. 
Costa, James. 2017. Revitalising language in Provence: A critical approach. New

York/Oxford: Wiley Blackwell \& Philological Society.

Coupland, Nikolas. 2010. The authentic speaker and the speech community. In Carmen

Llamas and Dominic Watts (eds.), Language and identities, 99-112. Edinburgh:

Edinburgh University Press.

Davies, Alan. 1991. The native speaker in applied linguistics. Edinburgh, Edinburgh University Press.

De Garis, Marie ed. et al. 1967. Dictiounnaire Angllais-Guernésiais [English-Guernesiais Dictionary]. Guernsey: La Société Guernesiaise. Revised editions published in 1967, 1982, and 2012.

Digital Greenhouse 2017a. Digital Greenhouse Guernsey. http://www.digitalgreenhouse.gg/, accessed October $19^{\text {th }}, 2017$.

Digital Greenhouse 2017b. Learn Guernesiais on the Digital Greenhouse App. http://www.digitalgreenhouse.gg/whats-happening/news/learn-guernesiais-on-thedigital-greenhouse-app/, accessed October $19^{\text {th }}, 2017$.

Dorian, Nancy C. 1980. 'Language shift in community and individual: the phenomenon of the laggard semi-speaker', International Journal of the Sociology of Language 25. $85-94$.

Duchêne, Alexandre and Monica Heller 2007. Discourses of endangerment: ideology and interest in the defence of languages. London: Continuum.

Fishman, Joshua A. (ed.) 1991. Reversing language shift: theoretical and empirical foundations of assistance to threatened languages. Bristol: Multilingual Matters.

Grinevald, Colette and Michel Bert 2011. 'Speakers and communities', in P. K. Austin and Sallabank (eds.), The Cambridge handbook of endangered languages. Cambridge: Cambridge University Press, 45-65. 
GLC (Guernsey Language Commission), no date a. Learning the language.

http://language.gg/learning the_language, accessed August 23rd, 2017.

GLC, no date b. Guernsey Language Commission YouTube channel.

www.youtube.com/user/Guernesiais/, accessed October 19 ${ }^{\text {th }}, 2017$.

GLC, no date c. Free translation service. http://language.gg/Free-translation-service, accessed October $19^{\text {th }}, 2017$.

GLC 2016. What is Speed Patois? https://www.youtube.com/watch?v=epa4yzC8GZQ, accessed Oct $5^{\text {th }}, 2017$.

GLC 2017. Guernsey Language Commission Facebook page, accessed August 18 ${ }^{\text {th }}, 2017$. https://www.facebook.com/Guernesiais/

Guernsey Press. 2016. Opinion. Guernsey Press November 10 2016.

Hinton, Leanne, and Hale, Ken eds. 2002. The Green book of language revitalization in practice. San Diego/Oxford: Academic Press.

Iris \& Dora, no date. Collymochon t-shirt. Facebook commerce page https://www.facebook.com/commerce/products/1298165653573228/?rid=135725943 $\underline{7628537 \& \mathrm{rt}=1 \& \text { preview_image } \mathrm{id}=1216546615105460}$, accessed Oct 22 $2^{\text {nd }}, 2017$.

Jaffe, Alexandra (ed.) 2012. Stance: Sociolinguistic Perspectives. Oxford: Oxford University $\underline{\text { Press. }}$

Johnson, Henry 2013. “The Group from the West”: song, endangered language and sonic activism on Guernsey', Journal of Marine and Island Cultures 1(2). $99-112$.

Holliday, Adrian. 2005. The Struggle to Teach English as an International Language. Oxford: Oxford University Press.

King, Jeanette. 2014. Revitalising the Maori language? In Peter K. Austin and Sallabank (eds.), Endangered languages: beliefs and ideologies in language documentation and revitalization: 215-230. Oxford: Oxford University Press/British Academy. 
Kroskrity, Paul V. and Margaret Field. 2009. Native American language ideologies: beliefs, practices, and struggles in Indian country. Tucson, AZ: University of Arizona Press.

Landry, Rodrigue and Richard Bourhis. 1997. 'Linguistic landscape and ethnolinguistic vitality: an empirical study', Journal of Language and Social Psychology 16. 23-49.

Marquis, Yan and Julia Sallabank 2013. 'Speakers and language revitalization: a case study of Guernesiais (Guernsey)', in Mari C. Jones \& Sarah Ogilvie (eds.): Keeping languages alive: documentation, pedagogy, and revitalization. Cambridge: Cambridge University Press, 169-180.

Marquis, Yan and Julia Sallabank. 2014. Ideologies, beliefs and revitalization of Guernesiais (Guernsey). In Peter K. Austin \& Sallabank (eds) Endangered languages: Beliefs and ideologies. Proceedings of the British Academy, 151-166. Oxford: Oxford University Press/British Academy.

Matras, Yaron, Hazel Gardner, Charlotte Jones, \& Veronica Schulman. 2007. Angloromani: A different kind of language? Anthropological Linguistics 49-(2). 142-184.

McCarty, Teresa L. (ed.) 2011. Ethnography and language policy. New York: Routledge.

Meek, Barbara A. 2011. We are our language: an ethnography of language revitalization in a Northern Athabaskan community. Tucson: University of Arizona Press.

Moya, P. M. L. 2000. 'Introduction: reclaiming identity’, in P. M. L. Moya \& M. R. HamesGarcia (eds.), Reclaiming identity: realist theory and the predicament of postmodernism, 2-26. Berkeley: University of California Press.

Nekvapil, Jiří V. \& Marek Nekula. 2006. ‘On language management in multinational companies in the Czech Republic', Current Issues in Language Planning 7(2\&3). $307-327$.

Nieldzielski, Nancy A. \& Dennis R. Preston 2003. Folk linguistics. Berlin : Mouton de Gruyter. 
Romaine, Suzanne 2002. 'The impact of language policy on endangered languages', International Journal on Multicultural Societies 4(1). 194212. www.unesco.0rg/shs/ijms/vol4/issue 2/art3, accessed October $22^{\text {nd }}, 2017$.

Romaine, Suzanne. 2006. Planning for the survival of linguistic diversity. Language Policy 5. $441-473$.

Sallabank, Julia. 2013. Can majority support save an endangered language? A case study of language attitudes in Guernsey. Journal of Multilingual and Multicultural Development 34. 332-347.

Sallabank, Julia. 2018. Purism, Variation, Change and 'Authenticity': Ideological Challenges to Language Revitalisation. European Review 26(1). 164 - 178.

Sallabank \& Yan Marquis. 2017b. Spelling trouble: ideologies and practices in Giernesiei/Dgernesiais/Guernesiais/Guernésiais/Djernezié ... . In Mari C. Jones \& Damien Mooney (eds): Creating orthographies foreEndangered languages, 235- 253. Cambridge: Cambridge University Press.

Sallabank, Julia \& Yan Marquis. 2017b2017. "We don't say it like that": Language ownership and (de)legitimising the new speaker of Guernesiais. In Michael Hornsby \& Cassie Smith-Christmas (eds): New Speakers of Minority Languages: Linguistic Ideologies and Practices, 67-90. Basingstoke: Palgrave Macmillan.

Shandler, Jeffrey. 2006. Adventures in Yiddishland: Postvernacular language and culture. Berkeley: University of California Press.

Sharrock, Wesley. 1974. On owning knowledge. In Roy Turner (ed.): Ethnomethodology, 45-53.. Harmondsworth: Penguin.

Skutnabb-Kangas, Tove, Luisa Maffi \& Dave Harmon. 2003. Sharing a world of difference. The Earth's linguistic, cultural, and biological diversity. Paris: UNESCO, Terralingua, and World Wide Fund for Nature. 
Spolsky, Bernard. 2004. Language Policy. Cambridge: Cambridge University Press.

Spolsky, Bernard 2009. Language management. Cambridge: Cambridge University Press.

Sutherland, William J. 2003. Parallel extinction risk and global distribution of languages and species. Nature 423.276279.

Valdés, Guadalupe. 2005. Bilingualism, heritage language learners, and SLA research:

Opportunities lost or seized? Modern Language Journal 89(3). 410-426. 